\title{
Can a Maize Price Band Work in Malawi?
}

\author{
Bob Baulch and Rosemary Botha
}

\section{Summary}

- Over the last twelve years, Government intervention has usually been insufficient to raise estimated farmgate maize prices above the floor established by the MoAFS's minimum farmgate price, while the ADMARC sales price has not acted as a ceiling price for consumers.

- The frequency of purchases and sales required to maintain floor and ceiling prices varies with the width of the price band and its height relative to market prices. This poses serious budgetary and logistic challenges.

- More attention should be paid to the timing of maize market interventions. ADMARC purchases of maize are needed early in the marketing season but NFRA releases and ADMARC sales of maize are required later during the lean season.

- Price volatility, operational challenges, and high costs make it very difficult for Malawi to stabilize maize prices using a price band combined with a buffer stock.

\section{Introduction}

Price band schemes have been used in many countries to try and set minimum and maximum prices between which staple food prices vary. This is typically done using a buffer stock scheme, which sells grain from a reserve when retail prices are higher than a pre-determined ceiling price and buys grain to store in the reserve when prices fall below a pre-determined floor price.

Malawi has attempted to stabilize the price of its main staple, maize, for many years. Since 1999, this has been the dual responsibility of the National Food Reserve Agency (NFRA), which manages the nation's Strategic Grain Reserve, and the Agricultural Marketing and Development Corporation (ADMARC), an agricultural marketing parastatal with an extensive network of depots and warehouses throughout the country. The precise division of responsibilities for maize price stabilization between the NFRA and ADMARC is unclear, although it is ADMARC which has the mandate to buy from farmers and sell to consumers while NFRA's principal role is to manage the Strategic Grain Reserve.

This note updates previous IFPRI analysis which examined, based on historical maize prices, how often ADMARC would need to intervene in different markets to defend a plausible range of ceiling and floor prices. The floor price corresponds to the minimum farmgate price announced by the Ministry of Agriculture and Food Security (MoAFS) at the beginning of each harvest season while the 
ceiling price corresponds to the sales price of maize at ADMARC depots. The price band is then the gap between the floor and ceiling price. To defend a set floor price, ADMARC would need to buy off any excess supply on the market, thereby creating an upward pressure on maize prices. Conversely, to ensure the ceiling prices are not exceeded, the NFRA would need to release maize for ADMARC to sell on the market to create a downward pressure and bring the prices down to the ceiling price. International experience indicates that defending floor/ceiling prices in all circumstances is a very expensive proposition.

To provide some historical background, Figure 1 plots average nominal maize prices between April 2008 and March 2020. As can be seen from the graph, estimated farmgate prices have on most occasions remained below the minimum farmgate prices announced by MoAFS, which are aimed at meeting farmers typical costs of production. IFPRI has recently conducted a crowdsourcing study with Farm Radio Trust, which found that 76 percent of farmers received less than the minimum farmgate price for the maize they sold (in the main 2020 marketing season). Figure 1 also shows that average retail maize prices have frequently been higher than the ADMARC sales price. ${ }^{1}$ Together these graphs show that maize prices have frequently moved out of the price band that aims to protect both producers and consumers. ${ }^{2}$

Figure 1: Average nominal maize prices (April 2008-March 2020)

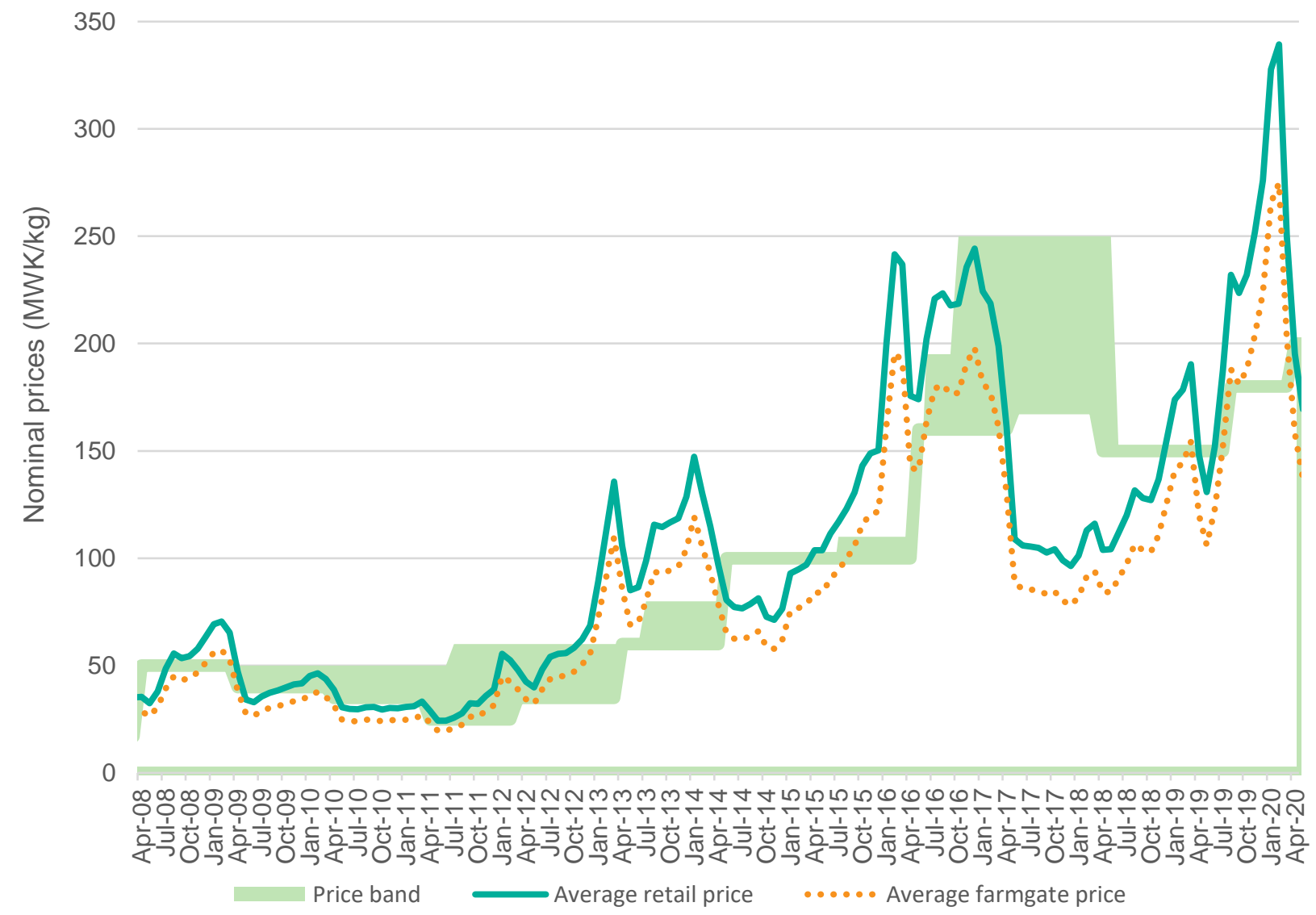

Source: IFPRI, based on MoAFS's Agricultural Marketing Information System.

Table 1 shows the percentage of months in which ADMARC would have needed to intervene (i.e., buy or sell maize) in order to defend selected price bands between April 2008 and March 2020. Generally, the frequency of intervention varies inversely with the width of the price band, with the lowest intervention frequency (25 percent) corresponding to the widest price band (MWK 100 to $300 / \mathrm{kg}$ ) and the highest (93 to 99 percent) to narrow price bands (of MWK 150 to 200/kg, and MWK 200 to $250 / \mathrm{kg}$, respectively). 
The frequency of intervention also varies with the height of the price band, which generally increases the further the price band is from the market price. With a price band that is set far below market prices, frequent sales are required to defend the ceiling price; but with a price band that is set above market prices, frequent purchases are needed to defend the floor price. If the price band is MWK 100 wide, the frequency of intervention increases from 54 percent to 86 percent as the band rises from MWK $100-200 / \mathrm{kg}$ to MWK $200-300 / \mathrm{kg}$. This is because the government needs to buy more to support farmgate prices the higher is the price floor above market prices. Getting the height of the price band 'just right' is crucial if a buffer stock is to be financially sustainable.

Table 1: Frequency of ADMARC intervention for selected price bands

\begin{tabular}{lccc}
$\begin{array}{l}\text { Real Price Band } \\
\text { (MWK/kg) }\end{array}$ & $\begin{array}{c}\text { Frequency of } \\
\text { intervention (\%) }\end{array}$ & of which \\
\hline $\mathbf{1 0 0 - 2 0 0}$ & 54.8 & 17.2 & 37.6 \\
$\mathbf{1 0 0 - 2 5 0}$ & 38.0 & 17.2 & 20.8 \\
$\mathbf{1 0 0 - 3 0 0}$ & 24.9 & 17.2 & 7.7 \\
$\mathbf{1 5 0 - 2 0 0}$ & 93.0 & 55.4 & 37.6 \\
$\mathbf{1 5 0 - 2 5 0}$ & 76.2 & 55.4 & 20.8 \\
$\mathbf{1 5 0 - 3 0 0}$ & 63.2 & 55.4 & 7.7 \\
$\mathbf{2 0 0 - 2 5 0}$ & 99.2 & 78.4 & 20.8 \\
\hline $\mathbf{2 0 0 - 3 0 0}$ & 86.2 & 78.4 & 7.7 \\
\hline
\end{tabular}

Source: IFPRI calculations.

Clearly, there is a seasonal element to maize price stabilization activities. Figure 2 shows the frequency of intervention by month needed to defend the range of floor and ceiling prices presented above. Between 2008 and 2020 intervention to defend floor prices was most important in the months of April, May, and June, when estimated farmgate prices fell below floor prices in 23 to 97 percent of months. These months represent the main harvest season for maize. Yet, with the exception of a few years, ADMARC has typically not started purchasing maize until July or August. ${ }^{3}$ In some years, such as 2016 and 2019, the late start to ADMARC and NFRA procurement probably destabilized rather than stabilized maize prices.

Figure 2: Frequency of required intervention by month

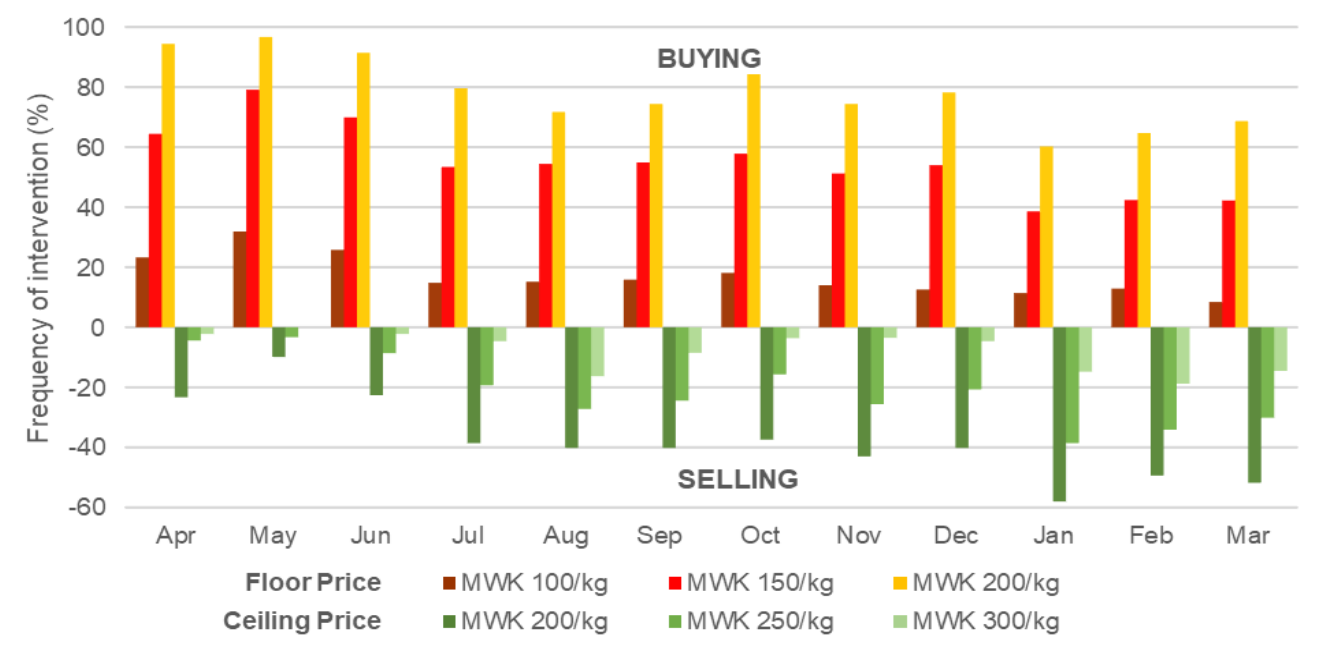

Source: Authors' construction. 
Similarly, the months during which ADMARC needed to sell maize to stabilize prices are January, February, and March. These months typically represent the lean season of maize. The months of January and February require the most ADMARC sales, with the frequency of intervention ranging from 15 to 58 percent depending on the ceiling prices chosen.

To conclude, our analysis of maize price bands in Malawi shows the following. First, over the last 12 years Government intervention has usually been unable to lift estimated farmgate maize prices above the floor set by minimum farmgate prices, while the ADMARC sales price has not acted as a ceiling price for maize consumers. Second, the frequency of intervention (i.e., public purchases and sales of maize) required to make floor and ceiling prices binding is substantial and varies with both the width of the price band and its height relative to market prices. The wider the price band, the lower the frequency of interventions. However, the further is the price band from market prices, the higher the frequency of maize purchases and sales. Except, for the widest and lowest price bands, public intervention to defend floor and ceiling prices is required more than half of the time, which poses serious budgetary and logistic challenges. Finally, more attention needs to be paid to the timing of maize market interventions, with ADMARC purchases of maize needed to counteract seasonal price declines earlier in the season but NFRA releases and ADMARC sales of maize required mainly during the lean season.

While a separate modeling exercise is required to estimate the volumes of stocks needed to stabilize maize prices, IFPRI estimates from 2016 suggest these are very large and would cost at least MWK 100 billion a year. International experience with buffer stocks in other countries also suggests that the budgetary costs of buffer stocks are high, though they can be reduced to some extent by use of adaptive price bands and international trade (Minot 2017; Wright 2012). However, Malawi's landlocked geography makes the latter more difficult and expensive than in coastal countries (Maître d'Hôtel et al. 2011). Furthermore, as with pure buffer stock interventions, there is a danger that mistimed trade interventions may destabilize rather than stabilize the domestic maize market.

To summarize, price volatility together with operational challenges and high budgetary costs make it very difficult for Malawi to stabilize either retail or farmgate maize prices using a price band combined with a buffer stock.

\section{ABOUT THE AUTHORS}

Bob Baulch is a Senior Research Fellow in the Development Strategy and Governance Division (DSGD) of IFPRI and Country Program Leader of the Malawi Strategy Support Program (MaSSP). Rosemary Botha is a Research Analyst with IFPRI Malawi.

\section{FURTHER READING}

\footnotetext{
Maître d'Hôtel, E., A. Alpha, R. Beaujeu, F. Gérard, and L. Levard. 2011. "Managing Agricultural Price Volatility in Africa: Context Matters for Policy Effectiveness." Perspective 12: 1-4. https://doi.org/10.19182/agritrop/00051

Minot, N. 2017. "Public Grain Reserves: International Experience and Lessons for Malawi." Presentation at IFPRI Malawi seminar, Lilongwe, Malawi, January 27. http://massp.ifpri.info/2017/02/02/ifpri-leads-discussion-on-costs-and-benefits-of-public-grain-reserves/

Wright, B. D. 2012. "International Grain Reserves and Other Instruments to Reduce Volatility in Grain Markets." World Bank Research Observer 27 (2): 222-260.
} 


\section{ENDNOTES}

${ }^{1}$ This graph and subsequent analysis is based on monthly maize price data prices collected by the Ministry of Agriculture and Food Security's Agricultural Marketing Information System. We use retail prices as they correspond to the ceiling prices that ADMARC seeks to defend. Farmgate price data were estimated from retail prices using a margin of MWK $0.81 / \mathrm{kg}$ based on IFPRI fieldwork.

${ }^{2}$ While ADMARC sales prices have generally been above the minimum farmgate prices set by the MoAFS, between August 2008 and April 2009, and again between July 2018 and July 2019, the ADMARCs sales price and MFG price were identical. During such times, Government should be prepared to subsidize all ADMARC's maize marketing and distribution costs.

${ }^{3}$ ADMARC's late purchase of maize may be linked to both the budgetary cycle (Malawi's national budget is usually not approved until late June or early July) and its desire not to purchase 'wet' maize.

The Malawi Strategy Support Program (MaSSP) is managed by the International Food Policy Research Institute (IFPRI) and is made financially possible by the generous support of the American people through the United States Agency for International Development (USAID), and by the UK Department for International Development (DFID). This publication has been prepared as an output of MaSSP and has not been independently peer reviewed. Any opinions expressed here belong to the authors and are not necessarily representative of or endorsed by IFPRI, the US or the UK government's official policies, or CGIAR.

\section{INTERNATIONAL FOOD POLICY RESEARCH INSTITUTE}

A world free of hunger and malnutrition

IFPRI is a CGIAR Research Center 